\title{
In the name of the European Union, the Member States and/or the European citizens?
}

\author{
Freya Clausen"
}

In the well-known words of Judge Pescatore, the Court of Justice of the then - European Communities had "une certaine idée de l'Europe" ("a certain idea of Europe"). ${ }^{1}$ The Court played a major role in the pursuit of that idea during the early years of the process of European integration. By virtue of the doctrine of direct effect, ${ }^{2}$ another former member of that Court added, the latter "[took] Community law out of the hands of the politicians and bureaucrats and [gave] it to the people"3. The Court's selfperception was that of a Court embodied in a "new European Volksgeist"4, acting as the "conscience" of the peoples of Europe". Was the Court then deciding in the name of the (Member States' or Union's) citizens? My contribution shall address this very question in the light of the (recent) debate on the Court's (democratic) legitimacy.

Legitimacy can be defined as "the quality of a body that leads people to accept its authority" ${ }^{6}$. Incontestably, the Court of Justice of the European Union (CJEU) holds and exercises wide ranging judicial powers, which

* Référendaire, Court of Justice of the European Union. The views expressed are personal to the author.

1 Pescatore, P. (1983), "The Doctrine of Direct Effect: An Infant Disease of Community Law", European Law Review 8, 155-157, 157.

2 Van Gend \& Loos, Case 26/62, Judgment of 5 February 1963, [1963] ECR 1.

3 Mancini, G.F. and Keeling, D.T. (1994), "Democracy and the European Court of Justice", Modern Law Review 57(2), 175-190, 186. The Court referred to the "[Member States'] nationals" in Van Gend \& Loos, supra note 2.

4 Schepel, H. and Blankenburg, E. (2001), "Mobilizing the European Court of Justice” In: G. de Búrca and J.H.H. Weiler (eds), The European Court of Justice. Oxford: Oxford University Press, 9-42, 11.

5 Ibid., 10, quoting Kakouris, C.N. (1995), "La Cour de Justice des Communautés européennes comme Cour Constitutionnelle: Trois observations” In: O. Due et al. (eds), Festschrift für Ulrich Everling (vol. 1). Baden-Baden: Nomos, 629-640, 632.

6 I owe this elegant definition to Ritleng, D. (2016), "The Independence and Legitimacy of the European Court of Justice" In: D. Ritleng (ed.), Independence and Legitimacy in the Institutional System of the European Union. Oxford: Oxford University Press, 83-124, 83. 
must be legitimate: the CJEU reviews, inter alia, the lawfulness of acts and the conduct of the European Union (EU)'s legislature and executive, as well as those of the Member States. It develops EU law through dynamic interpretation; its decisions ultimately determine EU citizens' rights and obligations and have an impact on highly sensitive areas of (national) policy. While, undoubtedly, the two courts composing the CJEU, namely the Court of Justice (hereinafter the Court) and the General Court (GC), exercise these judicial powers, the need for legitimacy is stronger for the Court than for the GC and the threshold of legitimacy is set at a higher level. ${ }^{7}$ That is certainly because, among the manifold functions conferred upon to the two courts, the most salient belong to the Court. It is the latter's caselaw that is most frequently in the limelight, which might sometimes raise concerns about the impact of EU law on national (constitutional) law, the Member States' sovereign rights ${ }^{8}$ and their domestic democracy. ${ }^{9}$ Following this path, I shall limit my contribution to the legitimacy of the Court. ${ }^{10}$

It is a well-known fact that the Court developed its creative interpretation of the founding Treaties in a rather uncontroversial way during the 1960s and 1970s. The situation changed drastically in the course of the 1980s. ${ }^{11}$ Ever since, both the legitimacy of the Court and its case-law have been subject to elaborate discussion and sometimes sharp criticism.

7 Epping, V. (1997), "Die demokratische Legitimation der dritten Gewalt der Europäischen Gemeinschaften”, Der Staat 36(3), 349-380, 366-374.

8 Mancini and Keeling, supra note 3, 183.

9 Grimm, D. (2017), The Constitution of European Democracy. Oxford: Oxford University Press, 97-101, 105-115, 191-202.

10 Additionally, I shall exclude the legitimacy of national judges exercising their "European mandate" from the scope of my contribution. For a broader analysis of that issue, see Pernice, I. (1996), "Die Dritte Gewalt im europäischen Verfassungsverbund", Europarecht 34, 27-43; Roland, S. (2011), "La légitimité du juge comme auteur du/de droit. L'exemple du juge communautaire ou comment poser la question de la légitimité du juge communautaire?" In: L. Fontaine (ed.), Droit et légitimité. Brussels: Bruylant/Nemesis, 191.

11 On possible reasons for this change: Dehousse, R. (1997), La Cour de justice des Communautés européennes. Paris: Montchrestien, 129-150; Weiler, J.H.H. (1999), "The Least-Dangerous Branch: A Retrospective and Prospective of the European Court of Justice in the Arena of Political Integration” In: J.H.H. Weiler (ed.), The Constitution of Europe. Cambridge: Cambridge University Press, 188-206. 
During the first peak of the debate on the Court's legitimacy in the course of the 1990 s, democracy played a minor role. ${ }^{12}$ While some authors addressed the democracy issue and pointed to its limits, they did so merely in the context of the selection of judges and their appointment to the Court. ${ }^{13}$ Several former judges even opposed any attempt to make the Court more democratic, ${ }^{14}$ as they considered that such attempts were liable to undermine the Court's necessary independence vis-à-vis the other EU institutions. They further rightly argued that a State-shaped democracy idea was unsuitable for the European Communities, today the Union. Accordingly, the Court's legitimacy was derived from other sources: the judges' independence, which was exceptionally identified as the source of the Court's "democratic legitimacy"15, the judges' legal expertise or the persuasiveness of the Court's decisions, which might "compensate its democratic deficit" 16 .

Nowadays, by contrast, scholars and judges explicitly address the issue of the democratic legitimacy of the Court ${ }^{17}$ and discuss to whom it should respond $^{18}$ or in whose name it should decide (the Union, the Member

12 The Court's contribution to the rise of the democratic principle in the European Communities (Union) during that period was generally acclaimed: Mancini and Keeling, supra note 3; Pescatore, P. (1974), "Les exigences de la démocratie et la légitimité de la Communauté européenne”, Cahiers de droit européen 10(5), 499514, 511-513. For a more recent analysis, see Potvin-Solis, L. (2018), "La Cour de justice et la démocratie" In: C. Haguenau-Moizard and C. Mestre (eds), La démocratie dans l'Union européenne. Brussels: Bruylant, 148.

13 Epping, supra note 7; Mancini and Keeling, supra note 3, 176.

14 Kakouris, supra note 5, 637-638; Pescatore, P. (2000), "La légitimité du juge en régime démocratique", Commentaire 90, 339-349; Schockweiler, F. (1993), "L'indépendance et la légitimité du juge dans l'ordre juridique communautaire", Rivista di diritto europeo 33(4), 671-680, 674, 676-679.

15 Kakouris, supra note 5, 638.

16 Koopmans, T. (1993), "Judicial activism and procedural law", European Review of Private Law 1(1/2), 67-81, 79.

17 Hong, Q.L. (2010), "Constitutional Review in the Mega-Leviathan: A Democratic Foundation for the European Court of Justice", European Law Journal 16(6), 695716; Tomuschat, C. (2006), "National Representation of Judges and Legitimacy of International Jurisdiction: Lessons from ICJ to ECJ?" In: I. Pernice et al. (eds), The Future of the European Judicial System in a Comparative Perspective. Baden-Baden: Nomos, 183-190, 187. Contra: Roland, supra note 10, 193-194.

18 De Witte, B. (2012), "Democratic Adjudication in Europe. How Can the European Court of Justice Be Responsive to the Citizens?” In: M. Dougan et al. (eds), Empowerment and Disempowerment of the European Citizen. Oxford: Hart, 129-144. 
States or EU citizens). ${ }^{19}$ A common understanding has developed that the judiciary of the EU - a union of States and of citizens - is to be evaluated no longer exclusively in its relation to the Member States and the legislative and executive branches of the EU, but also - if not predominantly - in its relation to EU citizens. In this regard, von Bogdandy's and Venzke's reading of Articles 9-12 TEU ${ }^{20}$ opens the door for an in-depth analysis of the Court's practices in the light of a reshaped democratic principle.

Against this backdrop, in my contribution I shall give an overview of the debate on the ways in which the legitimacy of the Court is construed and how the democratic argument contributes to this debate. Bearing in mind that the concept of democracy shall not be overstretched and that the specific needs of the judiciary must be preserved, I argue that the Court's democratic justification largely relies on its very creation, its composition and its judicial functions in a Union "based on the rule of law"11 (I). While I agree that the Court's legitimacy can be fostered by compliance with the requirements of fair trial, I do not believe that the democratic principles of transparency, openness, dialogue and participation should serve as a yardstick of the Court's (democratic) legitimacy (II). Finally, it is in the decision-making process, with regard to reasoning but also the definition of the level of judicial scrutiny, that the Court can generate authority, acceptability and, ultimately, legitimacy (III).

19 Wernicke, S. (2005), "In the name of the citizens! Art. I 1 of the Constitution and the European Court of Justice" In: I. Pernice and J. Zemanek (eds), A Constitution for Europe: The IGC, the Ratification Process and Beyond. Baden-Baden: Nomos, 235; Wernicke, S. (2007), "Au nom de qui? The European Court of Justice between Member States, Civil Society and Union Citizens”, European Law Journal 13(3), 380-407; Perillo, E. (2018), "La justice européenne: au nom de qui?", Revue des affaires européennes (2), 319-332.

20 Von Bogdandy, A. and Venzke, I. (2014), In whose name? A public Law Theory of International Adjudication. Oxford: Oxford University Press, $135 \mathrm{ff}$.

21 Les Verts v. Parlement, Case 294/83, Judgment of 23 April 1986, [1986] ECR 1339, 1365. 


\section{Institutional and functional legitimacy}

From an institutional and functional point of view, the Court's legitimacy is rooted in the Treaties ${ }^{22}$ which created the Court, vested it with its judicial powers and entrusted it with its mission. Since the Treaties were ratified by all the Member States in accordance with their respective constitutional requirements (that is to say with the approval of their national parliaments), they confer an indirect democratic basis to the legitimacy of the Court as an EU institution. For the same reason, that legitimacy is attached to the Statute of the CJEU (hereinafter the Statute), which forms part of the primary law of the EU. ${ }^{23}$ In an even more indirect manner, that legitimacy concerns the rules of procedures of the Court, which are established by the Court and approved by the Council. ${ }^{24}$ The Court's legitimacy derives from its composition and judges' independence (A) as well as its mission (B).

\section{A. The judges: judicial independence and composition of the Court}

The legitimacy of the Court is classically derived from the appointment of its judges and their independence, their impartiality, as well as their legal expertise. In this regard, the debate mainly concerns the selection and appointment of the judges, since the latter's personal qualities - independence, impartiality and highest legal qualifications ${ }^{25}$ - are not called into question and are guaranteed by a set of rules governing the office of the judge. ${ }^{26}$ The Court's independence is well protected against court-curbing

22 Epping, supra note 7, 353; Everling, U. (1995), "Die Rolle des Europäischen Gerichtshofes” In: W. Weidenfeld (ed.), Reform der Europäischen Union. Gütersloh: Bertelsmann, 256-264; Molinier, J. (2004), "La légitimité du juge communautaire" In: J. Raibaut and J. Krynen (eds), La légitimité des juges. Toulouse: Presses de l’Université des sciences sociales de Toulouse, 151-161, para. 2.

23 Article 51 TEU; Article 281 TFEU.

24 Article 253(6) TFEU. For a critical assessment of the rules governing the establishment and modification of the Statute and the Court's rules of procedure, see Keppenne, J.-P. (2017), "Les procédures de révision du cadre réglementaire des juridictions de l'Union", Cahiers de droit européen 53(2), 343-370.

25 Article 19(2) TEU; Article 253 TFEU; Article 2 of the Statute.

26 Michel, V. (2010), "Les juridictions communautaires européennes” In: H. Ruiz Fabri and J.-M. Sorel (eds), Indépendance et impartialité des juges internationaux. Paris: Pedone, 9-30, 16-20; Ritleng, supra note 6, 100-104. See also: Gaja, G. (2018), "Le rôle du juge ayant la nationalité d'un État membre intéressé à une 
mechanisms. ${ }^{27}$ It is also noteworthy that, nowadays, the Court itself pays great attention to the legality of its composition ${ }^{28}$ and the lawfulness of appointment procedures ${ }^{29}$ in order to guarantee the fundamental right to an independent and impartial tribunal.

A brief look at the historical evolution of the legal framework explains most of the controversy around the composition of the Court. Initially, during the negotiations that led to the creation of the European Coal and Steel Community, the Court was intended to become a rather typical international court. It was, therefore, to be composed of one judge per Member State and its members were to be appointed by a common accord of governments of the Member States. Yet, at a very late stage, the negotiations took a somehow unexpected turn and the Court was vested with powers of such original nature that it became a court of its own kind. ${ }^{30}$ The "one

affaire devant la Cour de justice" In: V. Cannizzaro et al. (eds), Liber Amicorum in onore di Antonio Tizzano. De la Cour CECA à la Cour de l'Union: le long parcours de la justice européenne. Turin: Giappichelli, 371-375, 372.

27 Kelemen, R.D. (2013), "The political foundations of judicial independence in the European Union" In: S.K. Schmidt and D. Kelemen (eds), The Power of the European Court of Justice. London: Routledge, 43-58. It should be noted, in this context, that some authors have recently criticized the anticipated end of the term of the British members of the Court, in particular that of the Advocate General, as an attempt to the Court's independence (Halberstam, D., "Could there be a Rule of Law Problem at the EU Court of Justice? The Puzzling Plan to let U.K. Advocate General Sharpston Go After Brexit“, available at https://verfassungsblog.de/co uld-there-be-a-rule-of-law-problem-at-the-eu-court-of-justice/, accessed 16 April 2020; Kochenov, D., "Humiliating the Court? Irremovability and Judicial SelfGovernance at the ECJ Today“, available at https://verfassungsblog.de/humiliatingthe-court/, accessed 16 April 2020). However, in my view, this situation has to be seen as a mere direct consequence of the United Kingdom's withdrawal from the EU.

28 The Court examined whether the GC's composition, which heard the case in first instance, complied with the requirements of an independent and impartial tribunal: Chronopost and La Poste v. UFEX and Others, Joined Cases C-341/06 P and C-342/06 P, Judgment of 1 July 2008, [2008] ECR I-4777, para. 46.

29 See, to that effect, Simpson v. Council and HG v. Commission, Joined Cases C-542/18 RX-II and C-543/18 RX-II, Judgment of 26 March 2020, [2020] ECR.

30 Malenovský, J. (2011), "Les éléments constitutifs du mandat des juges de la Cour de justice à l'épreuve du temps: l'iceberg commence à fondre", Il Diritto dell'Unione Europea 4, 801-836, 801-813. On the negotiation leading to the Paris Treaty and the Rome Treaties, see Lagrange, M. (1979), "La Cour de justice des Communautés européennes du plan Schuman à l'Union européenne" In: Mélanges Fernand Dehousse. La construction européenne (vol. 2). Paris/Brussels: Nathan/Labor, 127-135; Pescatore, P. (1981), "Les travaux du 'groupe juridique' dans la négociation des traités de Rome”, Studia diplomatica 34, 159-178. 
judge per Member State" rule, which is still valid today, ${ }^{31}$ and the appointment procedure remained unchanged at that stage. Under that procedure, candidates were at that time and continue to be designated by Member States pursuant to their own internal selection procedures. They were and continue to be appointed to the Court by common accord of the governments of the Member States for a renewable term of six years. ${ }^{32}$ In practice, the accord amounts to a pure formality, given that the Member States generally do not call into question the candidates put forward by other Member States. ${ }^{33}$ That procedure was subject to criticism: national selection procedures were regarded as executive-dominated and opaque, the judges' legitimacy derived exclusively from the appointment by governments - i.e. by the executive. Consequently, due to the proximity to national governments, the judges' independence and, ultimately, their legitimacy were called into question.

In response to part of that criticism, the Lisbon Treaty created an independent panel of experts, which hears the candidates designated by the Member States and issues an opinion on their suitability to perform their judicial duties. ${ }^{34}$ While the panel's opinions are not binding, they are followed in practice. This procedure prevents purely political nominations. ${ }^{35}$ Thus, the panel's creation has generally been welcomed, even though its functioning suffers from a lack of transparency. ${ }^{36}$ Its creation and work had a significant side effect on the transparency of and parliamentary involvement in national selection procedures. ${ }^{37}$

Yet, the Court's composition is still subject to criticism in three regards.

31 Article 19(2) TEU. Currently, there are 11 Advocates General in the Court.

32 Article 19(2)(3) TEU; Articles 253 and 254 TFEU.

33 Epping, supra note 7, 362; Malenovský, supra note 30, 815; Michel, supra note 26, 14; Ritleng, supra note 6, 92.

34 Article 255 TFEU.

35 Ritleng, supra note 6, 95.

36 Alemanno, A. (2015), "How Transparent is Transparent Enough? Balancing Access to Information Against Privacy in European Judicial Selections" In: M. Bobek (ed.), Selecting Europe's Judges: A Critical Review of the Appointment Procedures to the European Court. Oxford: Oxford University Press, 202-221.

37 For a critical assessment of that issue, see Dumbrovský, T. et al. (2014), "Judicial Appointments: The Article 255 TFEU Advisory Panel and Selection Procedures in the Member States", Common Market Law Review 51(2), 455-482. 
First, both scholars and judges claim that a non-renewable and longer term would further increase the judges' independence vis-à-vis their governments. ${ }^{38}$

Second, from a democratic viewpoint, some authors call for the direct involvement of the European Parliament in the appointment procedure ${ }^{39}$ alongside national representatives. Such an amendment would reflect the dual nature of the European concept of democratic representation. ${ }^{40}$ Both proposals are as old as the Court itself. ${ }^{41}$

Third, while it is indisputable that thanks to the "one judge per Member State" rule all domestic legal orders are represented in the Court, more recently authors have suggested that the Court's composition should be equally representative of EU citizens, in particular, in terms of gender balance and minority representation..$^{42}$ Nonetheless, under the current rules of appointment, where each Member State puts forward but one candidate and where the panel of experts hears the candidates individually, it is practically impossible to guarantee wider social diversity within the composition of the Court ${ }^{43}$ even if, as authors have suggested, a set of objective eligibility criteria were developed. ${ }^{44}$ That tendency might change if Member

38 Epping, supra note 7, 373; Léger, P. (2010), “Commentaire”, in Ruiz Fabri and Sorel, supra note 26, 31-35, 34; Louis, J.-V. (2006), "The Court in the Constitution: How Federal?” In: Pernice et al., supra note 17, 135-142, 137; Malenovský, supra note 30, 817-823, 828-829, 835; Pernice, supra note 10, 42; Ritleng, supra note 6, 98-100; Schockweiler, supra note 14, 676; Weiler, J.H.H. (2001), “Epilogue: The Judicial Après Nice" In: de Búrca and Weiler, supra note 4, 215-226, 225.

39 Pernice, supra note 10, 42; Ritleng, supra note 6, 100; Von Bogdandy, A. and Krenn, C. (2015), “On the Democratic Legitimacy of Europe's Judges: A Principled and Comparative Reconstruction of the Selection Procedures" In: Bobek, supra note 36, 162-180, 176-177. Contra: Schockweiler, supra note 14, 674.

40 Ritleng, supra note 6, 100; von Bogdandy and Krenn, supra note 39, 176-177.

41 Malenovský, supra note 30, 813. Later, in the 1980s, the Parliament attempted to play a role in selecting the judges (see, to that effect, Kenney, S.J. (1998-1999), "The Members of the Court of Justice of the European Communities", Columbia Journal of European Law 5(1), 101-133, 125-127).

42 That argument is based on the premise that "citizens are more likely to respect and trust courts whose personnel include people like themselves": Solanke, I. (2008-2009), "Diversity and Independence at the European Court of Justice", Columbia Journal of European Law 15(1), 89-121, 111; Shaw, J. (2001), "Gender and the Court of Justice” In: de Búrca and Weiler, supra note 4, 87-142, 116-118, $136 \mathrm{f}$.

43 De Witte, supra note 18, 134-135.

44 Solanke, supra note 42,102-111. I do not find the comparison, to this effect, with rules governing appointments to the CST particularly convincing (Ibid., 106), since the centralised appointment procedure was specific to that court. 
States were to put forward a list of several candidates ${ }^{45}$ rather than one single candidature.

\section{B. The functions of the Court}

The (democratic) legitimacy of the Court is also based upon the latter's mission to safeguard the rule of law and to ensure legal protection within the European legal order. This legitimacy discourse is twofold. So are its shortcomings and counterarguments.

First, the Treaties conferred upon the Court the very broad mission to ensure the respect of the law, ${ }^{46}$ vested it with wide-ranging judicial powers and created judicial remedies as well as a unique procedure of judicial dialogue with the national judges. The Treaties conferred upon the Court the exclusive power to render authentic interpretation of EU law. The Court's constitutional "duty" then is "to promote a Union based on the rule of law" 47 . The argument goes further in that as an EU institution, the Court is naturally called to pursue the aim of an "ever closer union among the peoples of Europe" 48 and to "promote [the EU's] values, advance its objectives, serve its interests" 49 . Here lay the foundations of the legitimacy of the Court in general and that of the latter's pro-integration case-law in particular.

The Court has built and strengthened that legitimacy by taking a leading role in the development and constitutionalisation of European integration: ${ }^{50}$ thanks to an original method combining textual, teleological, sys-

45 As suggested by von Bogdandy and Krenn, supra note 39, 178.

46 Article 19(1) TEU.

47 Ritleng, supra note 6, 105.

48 Mancini and Keeling, supra note 3, 186.

49 Article 13 TEU. See, to that effect, Ritleng, supra note 6, 105.

50 Lecourt, R. (1976), L'Europe des juges. Brussels: Bruylant; Kakouris, supra note 5, 638; Mancini and Keeling, supra note 3, 185; Ritleng, supra note 6, 108; Simon, D. (2006), "La légitimité du juge communautaire" In: L'office du juge. Actes du colloque du Sénat des 29 et 30 septembre 2006. Paris: Sénat, 447-468, 451-455, available at http://www.senat.fr/colloques/office_du_juge/office_du_juge42.html\#toc419, accessed 21 August 2018; Vandersanden, G. (2004), "Mais où est la Cour de justice d'antan?" In: P. Magnette (ed.), La Grande Europe. Brussels: Editions de l'Université de Bruxelles, 237-246. 
tematic and comparative interpretation, ${ }^{51}$ the Court gave meaning to imprecise concepts laid down in the Treaties, constitutionalised the latter, went on - exceptionally, but legitimately ${ }^{52}$ - to their "judicial revision" 53 and thereby promoted the integration process. It filled the gaps left open by the Treaties and/or the (paralysed) EU legislature, ${ }^{54}$ it empowered (ordinary) national courts to fully apply EU law and recognised directly applicable rights, but also obligations of EU citizens. ${ }^{55}$ Because of the traité-cadre nature of the Treaties and the lack of clear and complete legislation, the Court had no choice but to develop EU law consistent with its general mission and the objectives of the Treaties. ${ }^{56}$

However, the broad mission entrusted to the Court and the methods of interpretation it developed raised concerns of judicial activism and policymaking, ${ }^{57}$ allegedly in favour of European integration and to the detriment

51 Poiares Maduro, M. (2010), "Interpreting European Law - On Why and How Law and Policy Meet at the European Court of Justice" In: H. Koch et al. (eds), Europe: The New Legal Realism. Essais in Honour of Hjalte Rasmussen. Copenhagen: Djoef, 457-478, 461-463; Ritleng supra note 6, 106-107.

52 Gaudin, H. (2001), "Introduction - De la détention d'une fonction constituante par la Cour de justice” In: T. Debard (ed.), Les procédures de révision des traités communautaires: du droit international au droit constitutionnel. Brussels: Bruylant, 25$52,28-29,40-45$.

53 Jacqué, J.-P. (1986), “Note sous Partie écologiste Les Verts c/ Parlement européen”, Revue trimestrielle de droit européen 22 (1986) 491-510, 503, on the standing of the European Parliament as a defendant.

54 Pescatore, P. (1983), "La carence du législateur communautaire et le devoir du juge” In: G. Lücke et al. (eds), Rechtsvergleichung, Europarecht und Staatenintegration: Gedächtnisschrift für Léontin-Jean Constantinesco. Cologne: Karl Heymanns, 559-580.

55 Van Gend \& Loos, supra note 2; Costa v. ENEL, Case 6/64, Judgment of 15 July1964, [1964] ECR 585. On the importance of these cases, see Lecourt, R. (1991), "Quel eût été le droit communautaire sans les arrêts 1963 et 1964?” In: L'Europe et le droit: mélanges en hommage à Jean Boulouis. Paris: Dalloz, 349-361.

56 Mancini and Keeling, supra note 3, 186. During the first years of the European construction, only the Court was capable of pushing forward the process of integration: Cappelletti, M. (1979), "The 'Mighty Problem' of Judicial Review and the Contribution of Comparative Analysis", Legal Issues of European Integration 6(2), 129, 21-25.

57 Rasmussen, H. (1986), On Law and Policy in the European Court of Justice: A Comparative Study in Judicial Policymaking. Leiden: Brill. On the topic of judicial activism, see also: Dawson, M. et al. (eds) (2013), Judicial Activism at the European Court of Justice. Cheltenham/Northampton: Edward Elgar. 
of the Member States' interests and sovereignty. ${ }^{58}$ Yet, both that criticism and the legitimacy discourse reflect "differences of legal culture" with regard to the perception of the extent of discretion the courts enjoy. ${ }^{59}$ Accordingly, they reveal "different conceptions of the role of courts and their legitimacy" ${ }^{60}$. It follows that an abstract discussion about the discretion enjoyed by the Court, its self-restraint or its activism is circular and somehow "misconceived". ${ }^{61}$ Accusing the Court of activism often reflects a mere disagreement with the substance of the Court's decision. ${ }^{62}$

Second, scholars build and explain the Court's (democratic) legitimacy, by analogy to that of national constitutional courts, by reference to the Court's duty to ensure the respect of the rule of law and to theories of separation of powers or checks and balances. ${ }^{63}$ Put in a nutshell, legitimacy amounts to a court's "independence and obedience to law [...], as a counterbalance to political power based upon democratic legitimacy" or, in accordance with a slightly different view, to "the rule of law [seen] as a constitutive element of a well-established democratic system" in which the judge, as the ultimate guardian of its respect, enjoys democratic legitimacy ${ }^{64}$ Regardless of the approach one choses, it will, to a certain extent, be transposable to the case of the Court, which is frequently compared to constitutional or supreme courts. ${ }^{65}$ The CJEU forms indeed a "true third

58 See, for instance, the political reactions summarised by Weiler, J.H.H. (2008), "The Court of Justice in the limelight - again", Common Market Law Review 45(6), 1571-1579, 1571-1573.

59 Bengoetxea, J. (2010), "Reasoning from Consequences from Luxembourg” In: Koch, supra note 51, 39-56.

60 Poiares Maduro, supra note 51, 464.

61 Lenaerts, K. (2013), “How the ECJ Thinks: A Study on Judicial Legitimacy”, Fordham International Law Journal 36(5), 1302-1371, 1310.

62 Simon, supra note 50, 449.

63 See, in particular, Epping, supra note 7, 353; Lenaerts, supra note 61, 1305.

64 Rodriguez Iglesias, G.C. (2004), “The Judge Confronts Himself as a Judge” In: R. Badinter and S. Breyer (eds), Judges in Contemporary Democracy. New York: New York University Press, 275-285, 281-282.

65 Azoulai, L. (2008), "Le rôle constitutionnel de la Cour de justice des Communautés européennes tel qu'il se dégage de la jurisprudence", Revue trimestrielle de droit européen 44(1), 29-45; Epping, supra note 7, 367; Gaudin, H. (2000), "La Cour de justice, juridiction constitutionnelle?", Revue des affaires européennes 10(3), 209-222; Ronse, T. and Waelbroeck, D. (2001), "La Cour de justice, juridiction suprême" In: P. Magnette and E. Remacle (eds), Le nouveau modèle européen. Vol. 1: Institutions et gouvernance. Brussels: Éditions de l'Université de Bruxelles, 89-103; Vesterdorf, B. (2006), "A Constitutional Court for the EU?” In: Pernice et al., supra note $17,83-90$. 
branch", which is "legally and institutionally bound into the framework of the European Union". ${ }^{66}$ It interprets the Treaties and the system established by them in a sometimes creative and gap-filling manner. It reviews the lawfulness of the legal acts and the conduct of both the Member States and of the Union institutions. Thereby, it promotes the respect of the rule of law in the EU and exercises a democratic office.$^{67}$ The exercise of such judicial power is legitimate as long as it respects the constitutional constraints in which it is embedded; it is illegitimate when it encroaches upon the constituting power and/or the political decision-making power of the legislature or the executive.

The legitimacy of the Court also finds its source in the fact that the Court never has the final word. ${ }^{68}$ Its case-law can always be corrected or overturned by more democratically accountable bodies: the EU legislature can correct any interpretation of secondary law by modifying the relevant legislative provisions. Where the interpretation is based on a treaty provision, the authors of the Treaties might overrule the Court's interpretation through a Treaty amendment. ${ }^{69}$ So far, in practice, both the EU legislature $^{70}$ and the Member States as founding fathers have in most cases confirmed the Court's prior interpretations, even when those interpretations

66 Von Bogdandy and Venzke, supra note 20, 25.

67 Potvin-Solis, supra note 12, 150.

68 See, however, the vivid discussion on the identification by the Court of principles that even a formal treaty amendment cannot call into question: Boulouis, J. (1992), "Les avis de la Cour de justice des Communautés sur la compatibilité avec le Traité CEE du projet d'accord créant l'Espace économique européen”, Revue trimestrielle de droit européen 28(3), 457-464, 462; Dutheil de la Rochère, J. (1992), "L'EEE sous le regard des juges de la CJCE", Revue du marché commun 35, 603-612, 607, 612; Bieber, R. (1993), "Les limites matérielles à la révision des traités établissant les Communautés européennes”, Revue du marché commun 367, 343-350; Da Cruz Vilaça, J.L. and Piçarra, N. (1993), "Y a-t-il des limites matérielles à la révision des traités instituant les Communautés européennes?", Cahiers de droit européen 29(1-2), 3-37.

69 Gaudin, supra note 52, 37-38, 49-50. For a counter example, see Protocol 2 to the Maastricht Treaty, as mentioned by Dehousse, supra note 11, 132.

70 On the interplay between the Court and the EU legislature: Iliopoulou-Penot, A. (2015), "Réflexions sur la codification de la jurisprudence par le législateur européen" In: B. Bertrand et al. (eds), L'identité du droit de l'Union européenne: Mélanges en l'honneur de Claude Blumann. Brussels: Bruylant, 187-201. 
were at odds with the exact wording of the provision at stake. ${ }^{71}$ In other words, both the constituting power and the legislator appear to adhere to the Court's case-law thereby strengthening its legitimacy. ${ }^{72}$

That being said, however, there are critical voices to the effect that, while political overruling of the Court's case-law is theoretically possible, the practical hurdles are high and the prospect of a legislative or a constitutional overruling of the Court's decisions is rather remote. At the EU level, legislative procedures are arduous and apply without exception to the amendments of the existing legislation. The legislation often reflects difficult compromises reached after long negotiations between the Member States represented in the Council and, where the Treaty so requires, between the Council and the European Parliament. ${ }^{73}$ Save for the simplified procedure provided for in Article 48(6) TEU, Treaty amendments require Member States' common accord and ratification, which "[make] the overruling of primary law interpretations almost impossible" 74 . The alleged de facto impossibility of contradicting the Court's decisions sometimes raises concerns about the Court's legitimacy. ${ }^{75}$ Here again, "[t]he controversy is endless" 76 .

Whilst the abovementioned arguments offer a strong basis of legitimacy for the Court as a judicial body, they have been criticised. In the recurring debate about the Court's legitimacy, they seem insufficient to appropriately address the voices that are raised not against the body as such, but against the exercise of judicial power. The answer to the de-legitimating discourse is, hence, to be found somewhere else. Turning to von Bogdandy's and Venzke's proposal, courts are capable of creating and building their own legitimacy through open, transparent, participatory and deliber-

71 Two striking examples can be mentioned in that context: first, the confirmation, in the Maastricht Treaty, of the Parliament's locus standi, as defined in European Parliament v. Council, Case C-70/88, Judgment of 22 May 1990, [1990] ECR I-2041, para. 27, and, second, the constitutionalisation of the Court's catalogue of the fundamental rights in the Charter of Fundamental Rights.

72 Simon, supra note 50, 467.

73 See the very strong objections to such reasoning by Weiler, J.H.H. (2013), "Epilogue: Judging the Judges - Apology and Critique” In: M. Adams et al. (eds), Judging Europe's Judges. The Legitimacy of the Case Law of the European Court of Justice. London: Hart, 235-254, 245-246.

74 De Witte, supra note 18, 142-143. Compare: Kelemen, supra note 27, 45-46.

75 Favoureu, L. (2001), "Rapport de synthèse: 'L'euroscepticisme du droit constitutionnel"' In: H. Gaudin (ed.), Droit constitutionnel, droit communautaire: Vers un respect constitutionnel réciproque mutuel?. Aix-Marseille: Economica, 379-390, 388.

76 Ritleng, supra note 6, 111. 
ative procedures and sound decisions. I shall address both lines of argumentation.

\section{Procedural legitimacy}

The judicial process receives little or no attention in the debate about the Court's legitimacy. It is generally held that legitimacy flows from the respect of the requirements of a fair trial, openness, neutrality and independence. ${ }^{77}$ The Court acts legitimately where it duly respects the applicable procedures and guarantees the parties a fair trial. ${ }^{78}$ However, the question of whether the Court should "develop the judicial process in light of the democratic principle" as far as it pertains to openness, transparency and public dialogue or participation, ${ }^{79}$ remains unanswered in the doctrine discussing the Court's legitimacy. In my view, regardless of their topicality or relevance, such considerations have limited potential for generating or fostering the Court's legitimacy. ${ }^{80}$

First of all, I have some difficulty in seeing how and to what extent such democratic principles as transparency, openness, dialogue and participation are intended to apply to the Court in the exercise of its judicial functions. It is true that Article $11 \mathrm{TEU}$, which calls for a transparent dialogue with EU citizens, is applicable to "the institutions", among which is the CJEU. ${ }^{81}$ However, this fact "may be perceived as a sign of the arguable lack of reflection of the Treaty regarding the meaning and implications of participation as one of the foundations of democracy in the Union" 82 . This is all

77 Everling, supra note 22, 256.

78 With regard to procedural fairness requirements, see: Ritleng, supra note 6, 84.

79 Von Bogdandy and Venzke, supra note 20, 171.

80 Not to mention that the criticism the Court faces does not come from the citizens, but rather from the Member States, which accuse it of judicial activism (Ritleng, supra note 6,112). Since Member States may plainly participate in all stages of all the proceedings both in preliminary reference procedures and in direct actions, I do not think that any possible improvements in that respect could adequately address that kind of criticism.

81 Von Bogdandy and Venzke, supra note 20, 152.

82 Mendes, J. (2011), "Participation and the Role of Law After Lisbon: A Legal View on Article 11 TEU", Common Market Law Review 48(6), 1849-1878, 1869. Scholars tend to establish a link between this provision and the policy making: Curtin, D. (2012), "The Role of Judge-made Law and EU Supranational Government: A Bumpy Road from Secrecy to Translucence” In: Dougan, supra note 19, 101-127; Grewe, C. (2007), “Article I-47” In: L. Burgorgue-Larsen et al. (eds), Traité établis- 
the more true since the democratic principle sketched out in this article is further substantiated in Article 15(3) TFEU on access to documents, to which the Court is "subject [...] only when exercising [its] administrative tasks".

Second, it is necessary to strike a satisfying balance between any call for openness, transparency, public dialogue and participation with the requirements of the sound functioning and administration of justice. Judicial proceedings are different from political processes and do not offer an appropriate arena for a democratic, public, political debate. In other words, the need for transparency is less stringent in judicial proceedings compared to political and, in particular, legislative activities; the time-factor is important and the procedural rights of the parties to the proceeding must be guaranteed. ${ }^{83}$ Among these, I shall mention the "right to defend their interests free from all external influences and, in particular, from influences on the part of members of the public" in direct actions. ${ }^{84}$

Finally, the proceedings before the Court involve a fair amount of transparency, openness and participation thanks to the publication of a notice on every case brought to the Court in the Official Journal of the EU, the organisation of a thorough debate in preliminary references procedures, ${ }^{85}$ the admissibility of third party intervention in direct actions, the fact that hearings are public, the public delivery of the Court's decisions and, finally, the publication of judgments in 23 official languages of the EU. Having said that, there is always room for potential reforms. In particular, when it comes to the procedure: the national court's order for reference under Article 267 TFEU and written submissions could be made accessible to the general public in the course of or in the aftermath of the proceed-

sant une Constitution pour l'Europe: Commentaire article par article (vol. 1). Brussels: Bruylant, 624-633.

83 As stressed by von Bogdandy and Venzke, supra note 20, 178.

84 Breyer v. Commission, Case T-188/12, Judgment 27 February 2015, [2015] ECR, para. 119. The GC stressed that procedural documents are only served to the parties and are not to be made available to the public; it considered that the parties to the proceedings before it act unlawfully where they publish such documents on the internet. Upon appeal, the Court confirmed that position: Commission $v$. Breyer, Case C-213/15 P, Judgement of 18 July 2017, [2017] ECR, para. 62.

85 In accordance with Article 23(1) of the Statute, all parties to the proceedings before the referring judge, all the Member States, the Commission and the author(s) of the act the validity or interpretation of which is in dispute, are entitled to participate in the debate before the Court. An even larger debate is organised where one of the fields of application of the Agreement on the European Economic Area is concerned (Article 23(3) of the Statute). 
ings. Upon the closure of proceedings in direct actions, public access to the record or even the case-file could be granted. ${ }^{86}$ In cases of high social or political importance, oral hearings could be broadcast or webcast; ${ }^{87}$ the report for a hearing might be re-introduced; ${ }^{88}$ third party intervention in direct actions could be construed more openly ${ }^{89}$ and, more generally speaking, the access of so called "non-privileged" applicants to court could be broadened..$^{90}$ Yet, these questions go beyond the (traditional) legitimacy debate.

When it comes to the decisions of the Court, whilst the judges' collegiate deliberations are secret by their very nature, ${ }^{91}$ both judgments and Advocate Generals' opinions are public. "The public dialogue between the Court and its Advocates General plays an essential part in guaranteeing the transparency and intelligibility of the judicial process at the Court of Justice." 92 This, however, is deemed insufficient and scholars call for the

86 For further reading on this issue: Alemanno, A. and Stefan, O. (2014), "Openness at the Court of Justice of the European Union: Toppling a Taboo", Common Market Law Review 51(1), 97-139, 121-127.

87 Ibid., 127-130, 132.

88 Ibid., 130, 132-133. The virtues of the report for the hearing are at least twofold: on the one hand, since a paper/hard copy of the report is made available to the public before the hearing, the audience present in the courtroom has the means to grasp the gist of the case. On the other hand, the report for the hearing offers the parties a possibility to verify whether the judges have correctly understood the context of the case and their arguments.

89 By virtue of Article 40 of the Statute, whilst Member States and EU institutions have a right to intervene in any case before the Court, EU citizens, companies, non-governmental organisations et cetera fall into the category of "unprivileged" interested parties that must show "an interest in the result of a case submitted to the Court" and are not entitled to intervene in cases between Member States, between EU institutions or between Member States and EU institutions. Scholars call for a more open third party intervention: de Schutter, O. (2005), "Le tiers à l'instance devant la Cour de justice de l'Union européenne” in: H. Ruiz Fabri and J.-M. Sorel (eds), Le tiers à l'instance devant les juridictions internationales. Paris: Pedone, 85-104, 102.

90 On this difficult topic and on the implications of the Lisbon Treaty, see, inter alia, Lenaerts, K. (2009), "Le traité de Lisbonne et la protection juridictionnelle des particuliers en droit de l'Union", Cahiers de droit européen 45(5-6), 711-745; Coutron, L. (2010), "L'héritage de l'arrêt UPA", L'actualité juridique: droit administratif $10,548-556$.

91 Article 35 of the Statute.

92 Sharpston, E. (2009-2010), "Transparency and Clear Legal Language in the European Union: Ambiguous Legislative Texts, Laconic Pronouncements and the Credibility of the Judicial System", Cambridge Yearbook of European Legal Studies 12, 409-423, 420. 
admission of dissenting opinions. ${ }^{93}$ Such opinions by the judges in the minority, the argument goes, would result in the more discursive and more exhaustively reasoned decisions and would offer the public a better insight into all possible outcomes that have been discussed. The introduction of such opinions is, however, highly "unlikely" in practice. ${ }^{94}$ This brings me to last aspect of the legitimacy debate: the grounds for the decisions.

\section{Legitimacy through sound and reasoned decisions}

Scholars insist on sociological legitimacy, i.e. the acceptance of the Court's case-law by Member States, EU institutions, citizens, litigants, et cetera. ${ }^{95}$ The Court can generate such acceptance by adopting sound, persuasive, lawful, reasoned and acceptable decisions and, thereby, foster its own legitimacy ${ }^{96} \mathrm{~A}$ full and transparent reasoning allows for "democratic control"97 or responsiveness ${ }^{98}$ through public debate in the aftermath of proceedings. It is all the more important as the Court's rulings are not subject to an appeal and the Court cannot and shall not be held accountable for its caselaw in front of any external body. ${ }^{99}$

93 In favour of the introduction of dissenting opinions: Höreth, M. (2011), "Richter contra Richter. Sondervoten beim EuGH als Alternative zum 'Court Curbing', Der Staat 50(2), 191-226; Perju, V. (2009), "Reason and Authority in the European Court of Justice", Virginia Journal of International Law 49(2), 307-378; Weiler, supra note 38,225 . In order to avoid increased pressure on the independence of the judges, the call for such opinions usually goes hand in hand with proposals of a non-renewable and longer term of office. Contra: Schockweiler, supra note 14, 676.

94 De Witte, supra note 18, 141. See also: Alemanno and Stefan, supra note 86, 132.

95 For further reading: Pollack, M.A. (2017), "The legitimacy of the Court of Justice of the European Union”, available at https://papers.ssrn.com/sol3/papers.cfm?abstr act_id=2911836, accessed 17 August 2018, 1-56, 32-55.

96 The "quality of analysis [...] is one of the very foundations of its legitimacy": Vesterdorf, supra note 65,85 .

97 Bengoetxea, supra note 59, 56.

98 Pernice, supra note 10, 40.

99 Be it in front of the Ombudsman, the Court of Auditors or the European Parliament: De Witte, supra note 18, 136-137. 
The Court recognises the importance of the grounds for its decisions and elevates its duty to provide reasons ${ }^{100}$ to a public policy rule. ${ }^{101}$ The style of the Court's decisions has evolved over the years. ${ }^{102}$ Nowadays, it can be seen as a middle path between the French elliptic style and the more discursive style found in decisions by the German Federal Constitutional Court. ${ }^{103}$ Yet, in particular with regard to decisions on preliminary references, the Court faces criticism, for "[n]ot every judgment emanating from [it] is a model of lucidity and clarity" 104 . The Court's style of reasoning is sometimes perceived as giving the impression that "the outcome [of a case] is inevitable"105. Judgments, such as Ruiz Zambrano, Mangold or Kücükdeveci, ${ }^{106}$ are said to be "too cryptic and apodictic" 107 . The interesting suggestions that judgments should be read not individually but in a broader context of cases, given that the case-law is built on a step-by-step basis, ${ }^{108}$ are contested. ${ }^{109}$ The Court is criticized for developing its case-law in a purely "self-sufficient manner" 110 . In other words, it is said that the Court should offer comprehensive and sound reasoning, provide a full analysis of all arguments put forward, explain all considerations that underlie an interpretation, maybe even its consequences, and engage in open discussion with academic and political voices and precedents. ${ }^{111}$ The admission of dissenting opinion could ease the way towards more discursive judicial reasoning. ${ }^{112}$

100 Article 36 of the Statute.

101 On the GC's duty to state reasons: Mindo Srl v. European Commission, C-652/11 P, Judgment of 11 April 2013, [2013] ECR, paras 29-30; European Ombudsman $v$. Claire Staelen, C-337/15 P, Judgment of 4 April 2017, [2017] ECR, para. 85.

102 De Witte, supra note $18,138$.

103 Ritleng, supra note 6, 120.

104 Sharpston, supra note 92, 416.

105 De Witte, supra note 18, 138-139 (emphasized in the original text).

106 Mangold, C-144/04, Judgment of 22 November 2005, [2005] ECR I-9981; Kücükdeveci, C-555/07, Judgment of 19 January 2010, [2010] ECR I-365; Ruiz Zambrano, C-34/09, Judgment of 8 March 2011, [2011] ECR I-1177.

107 Ritleng, supra note 6, 120.

108 Lenaerts, supra note 61, 1350-1369. For further reading on this idea: Bertrand, B. (2012), "Les blocs de jurisprudence", Revue trimestrielle de droit européen 48(4), 741-770.

109 Weiler, supra note 73, 248-251 (in response to Lenaerts, supra note 61).

110 Without taking into consideration national constitutional law: Favoureu, supra note 75, 389-390.

111 See, inter alia: Bengoetxea, supra note 59; De Witte, supra note 18, 138-139; Kakouris, supra note 5, 639.

112 Supra, part II. 
Furthermore, as a result of the manifold challenges and criticisms related to the Court's alleged judicial activism and self-sufficiency, scholars develop new methods of adjudication and reasoning with regard to the context in which the Court operates. Whether this context is analysed in terms of constitutional pluralism ${ }^{113}$ or of the EU as a Fédération ${ }^{114}$ or in a less determined manner, the general idea is that the Court should take into account not only the interests of the EU and its law, but also "the possible reception of its decisions in Member States" and "the broad spectrum of diverging social and cultural conceptions". ${ }^{115}$ The Court's reasoning should "reflect the dialogical nature of European Constitutionalism" and the Court should "demonstrat[e] in its judgments that national sensibilities were fully taken into account". ${ }^{16}$ In practical terms, these proposals have an effect not only on the reasoning, which should become "more discursive, analytic, and conversational" 117 , but also on the level of scrutiny. It is said that the Court might show greater deference to Member States' constitutional identity and sensitivities and recognise a broader margin of their discretion (and their domestic courts). While this discussion barely refers to democratic legitimacy, it largely echoes von Bogdandy's and Venzke's proposals.

These proposals have found some response in the Court's recent caselaw. The Court appears to show greater deference to considerations of national identity and to secondary law (reflecting compromises reached within the Council and with the Parliament) and grants both the Member States and the Union's legislator a rather large margin of discretion. ${ }^{118}$ Whether the Court does indeed strike a satisfying balance between national and EU interests in every single case certainly depends on the

113 Azoulai, supra note 65; Poiares Maduro, M. (2007), "Interpreting European Law: Judicial Adjudication in a Context of Constituional Pluralism", European Journal of Legal Studies 1, 137-154; Poiares Maduro, supra note 51, 457; Ritleng, supra note $6,118-124$.

114 Roland, supra note 10, 222-230.

115 Timmermans, C. (2004), “The European Union's Judicial System”, Common Market Law Review 41(2), 393-405, 398.

116 Weiler, supra note 38, 219, 225.

117 Ibid., 225.

118 Bailleux, A. (2018), "Du constitutionnalisme supranational au cosmopolitisme républicain? Citoyenneté, droits fondamentaux et libre circulation dans la jurisprudence de la Cour de justice" In: L. Potvin-Solis (ed.), Le statut d'État membre de l'Union européenne. Brussels: Bruylant, 177-203. See also Ritleng, supra note $6,121-125$. 
assumptions on which different commentators base their analysis. I shall leave this question open at this point.

It follows from the foregoing that the legitimacy of the Court is strongly based on a combination of various factors pertaining to the Court's very creation, its composition, its mission, its functioning and working methods. While the Court actively contributed to strengthening this legitimacy over the years, it faces criticism which at times can be hostile, most often for its alleged pro-integration bias and activism. The most appropriate answer to such criticism is certainly to be found in the Court's working methods, reasoning, and balancing of all interests at stake.

The foregoing considerations, however, do not bring me any closer to answering the question in whose name the Court decides. On the basis of a natural reading of its case-law, one might simply observe that, in coherence with its status of an EU institution, the Court "serve[s the EU's] interests, those of its citizens and those of the Member States" (Article 13 TEU). From a substantive point of view, the Court decides, depending on the case, in the name of one of these three addressees, rather than any other.

If the Court's legitimacy is to be embedded in the EU's concept of democracy, I should stress the undisputed fact that the EU's democratic legitimacy rests with both the Member States and EU citizens. ${ }^{119}$ Consequently, and following von Bogdandy and Venzke's approach, I should conclude that the Court decides in the name of both the peoples of the Member States and the EU citizens. Yet, the wording ultimately points to the very same group of individuals, i.e. the citizens of the Union. ${ }^{120}$ As the Court put it itself, "Union citizenship is destined to be the fundamental status of nationals of the Member States"121. Is it then possible to conclude that the intention of the Court itself is to decide in the name of EU citizens in the first place? ${ }^{122}$ While such a symbolic understanding of that case-law will, beyond any doubt, please the pro-integration public, it

119 Thus, Perillo, supra note 19, 332, considers that the EU Courts decide "in the name of the citizens and the Member States of the EU".

120 As Pernice, supra note 10, 30, put it, "Legitimationsbasis [und] Adressatenkreis hoheitlichen Handelns sind hinsichtlich der EG statt des Volkes eines Staates die Völker und damit die Bürger aller durch die Gemeinschaftsverfassung verbundenen Staaten" (emphasis added).

121 Grzelczyk, Case C-184/99, Judgment of 20 September 2001, [2001] ECR I-6193. This statement concerns the mobile citizens, which exercised their freedom to move.

122 To that effect, see Wernicke (2007) and (2005), supra note 19. While Wernicke mainly based his proposal on the Article I-1 of the Treaty establishing a Constitution for Europe, which provided that "[r]eflecting the will of the citizens and States 
might encounter criticism emanating from a more Eurosceptic public. Ultimately, silence may then well be golden; it recognises that the point of reference for the Court's legitimacy is to some extent undetermined ${ }^{123}$ and that, depending on the case the Court is called upon to decide, it draws in varying proportions from those mutually enhancing sources.

of Europe to build a common future, this Constitution establishes the European Union" (emphasis added), he also referred to the Court's case-law on EU citizens' rights and obligations. See also Epping, supra note 7, 357. That author argues that in the absence of a European demos the Court's legitimacy might well be constructed by reference to the EU citizens.

123 Roland, supra note 10, 229-230. 
